\title{
Henderson, N. (Ed.) (2007). Resilience In Action: Practical Ideas for Overcoming Risks and Building Strengths in Youth, Families, and Communities. Paso Robles, CA: Resiliency in Action, Inc. 248 p., ISBN: 0-9669394-3-3.
}

Reviewed by Mag. VANJA R. Kiswarday, University of Primorska

NAN Henderson, M.S.W., is an internationally recognized author, trainer, and consultant on fostering human resiliency in youth, adults, families, and organizations. Her publications on this subject are used in more than 25 countries and have been translated into Spanish and Russian. She is co-founder and President of Resiliency In Action, Inc., a training organization in Southern California. She has been a trainer for hundreds of school districts, and social service and community agencies. The PA Dept. of Education has recently mandated Ms. Henderson's resiliency model to be used in every PA school.

The precedent for a paradigm shift from risk to resilience is emerging in the scientific literature as a consequence of the inadequate effectiveness of deficit models, on the one hand, and, on the other hand, as an answer to a challenge of longitudinal research evidence showing that, despite high risk status or exposure to adversities, about one third of children manage to succeed, to function positively and to successfully adapt to life (Masten \& Powell, 2003, p. 2). The phenomenon has been defined as resilience - an inherent or fostered capacity or response mechanism within all individuals, organisations and communities that is used to overcome significant challenges (Ibid, p. 4). Protective factors or mechanisms are influenced by three major domains: individual personality attributes or dispositions, family characteristics, and environmental influences (exosystems, e.g., peers, school, community). An individual, especially a child or young person, daily participates in many different systems (family, school, cultural, recreational, social, religious environments) that mutually interact with his/her development. Due to such reciprocal associations and the diverse influences on the child's development and adjustment status across different systems, the resiliency theory framework is guided by Bronfenbrenner's ecological theory (Luthar, Chichetti \& Becker, 2000, 
p. 554). In regard to Bronfenbrenner's bio-socio-ecological model, all of these systems interdependently interact with each other. Thus risk and protective factors operate across settings and at different levels in different environments (Masten, 2008; Clay, 2005). This confers a responsibility to foster resiliency in the school system as one of most important systems for children and young people, as well as for the community at large.

Among several models that promote resilience Henderson's Resiliency model most coherently addresses the aims, objectives and guidelines of quality education recommended by the European Parliament and the Council ("Progress towards the Lisbon objectives in education and training", 2005) and national educational policy (ZOsnF, 2007). The model emphasizes the process and aspires to create and provide quality environmental conditions within the school context, that promote equality, inclusion, learning efficiency, the importance of acquiring life skills and key competences for lifelong learning. When these environmental conditions are strengthened they also take the role of environmental protective factors and mechanisms for students.

The book Resiliency in Action aims to share and promote practical means and evidence derived from recent scientific research findings on resiliency. Contributors with different backgrounds and experience with resiliency (scientific researchers, professionals, individuals, schools, and communities) challenge the deficit-based approach towards a paradigm shift that fosters resiliency approach and focus sights on communicating "What is right with you is more powerful than anything that is wrong with you" (p. vi). Contextually, the book is divided into seven parts: The Foundations of Resiliency; Resiliency and Schools; Resiliency and Communities; Resiliency Connections: Mentoring, Support and Counselling; Resiliency and Youth Development; Resiliency and Families; and Resiliency and the Brain.

From the six chapters within Part One, we can gain an insight into the foundations of resiliency. Researcher Bonnie Benard introduces readers to the fundamental research that has enabled scientists to identify the correlates and markers of good adaptation among young people at risk. An important finding for prevention and education is that resiliency is not a generic trait but rather an inborn capacity for self-righting, transformation and changes that needs to be guided and supported through development. Ideally, a resilient attitude should become a way of living, because fostering resiliency 
operates at a deep structural, systemic, human level that is communicated via relationships, beliefs, mutual interaction and opportunities for participation. Benard emphasises the importance of focusing on the process rather than on the programme. Further, Nan Henderson presents the Resiliency Model, based on the research findings of individual and environmental protective factors and mechanisms. She has designed the Resiliency Wheel, a set of strategies that can be implemented in various circumstances to foster resiliency. She considers the Caring and support factor to be the most valuable and fundamental of all of the protective factors in the Resiliency Wheel, as it enables the creation of the relationships and environment that genuinely care for the child. It represents the base from which all of the other five factors emerge: High, but realistic, expectations for success; Opportunities for a "meaningful contribution" to others; Positive bonds and connections; Clear boundaries; and Life skills. The Caring and support dimension is strongly connected with learning engagement, efficiency and competence gathering. We can agree that the Resiliency Wheel seems logical and in full accordance with modern education curricula, but the evidence of the low learning motivation, low efficacy, numerous mental health problems among young students, bullying, school dropouts, etc., that appear so frequently in everyday school practice does not reflect this logical accordance. As Galimberti (2010, pp. 2747) points out, there is a major lack of emotions, relations and connectedness in our schools. Students remain untouched, unchallenged and uninvolved if the learning process passes them by without engaging both emotion and cognition. We can critically ask ourselves as teachers and adults: Are we giving students enough opportunities to participate in an active and creative way? Where else are students testing and using their acquired knowledge and skills besides in formal assessments? We encounter so many problems with discipline, inappropriate, even aggressive behaviour; it is difficult to respect the rules if there is simply a lack of respect for people and positive relations. It happens so often that teachers strongly support knowledge rather than students! In such circumstances the Resiliency Wheel may serve perfectly as a guideline for rethinking educational practice, aims and priorities.

Dr Emmy Werner is one of the pioneers in the field of resiliency research. After over 30 years experience of longitudinal studies she notes a tendency toward fostering resiliency and a great deal of interest in this field. However, she warns us to be prudent in determining whether and when someone is resilient, and with regard to 
our expectations related to this. She is sceptical about the effectiveness of short programmes that aim to foster resiliency, but she looks forward to a common strength-oriented mindset that fosters resiliency. Research evidence show that resiliency is not fixed and stable but that it changes through time and different situations, even within an individual as he or she develops. Competences and success in salient developmental tasks are crucial for positive adaptation, and later for positive self-confidence. This interconnection of individual and environmental protective factors and mechanisms reflects the important role of schools, or rather teachers. The latter appear as important adults who "provide children with a secure basis for the development of trust, autonomy, initiative and competence" (p. 23) and have good opportunities to make a difference and shift a child from risk to resiliency. The theory is followed by profiles of two young people who demonstrate resiliency in their life experience, as well as a strength-based approach to interventions with children exposed to domestic violence.

In the nine chapters in Part Two, resiliency is surveyed in a school context through research that forms the basis of a model of effective school reform. Educational changes and resiliency-building factors both take into account and seek to improve the same educational aspects (school's purpose, the nature of knowledge and learning, teaching methods, curriculum, leadership, decision making and assessment - see scheme, p. 61). Henderson presents extensive validation of the Resiliency Wheel, which, by addressing six protective environmental conditions, promotes improvement of school climate, provides opportunities for social-emotional learning and key competence gathering, and supports the development of students' resiliency. Like a great deal of other research on effective learning, the research in question shows that the way students experience their school day affects student achievement just as much as the academic aspect does. Thomsen, who perceives schools and good educational practice as potentially ideal settings where positive youth development becomes inherent, underlines the importance of brain-based intelligence, the employment of multiple intelligences and learning style awareness, character building, service-learning, peer leadership, cooperative learning and the mentoring approach. Henderson exposes the power and prevention effect of focusing the common opinion and norms toward positive goals, by simply refocusing data to emphasise positive behaviour instead of warning about negative examples (Chapter 
8). Every educational process, especially when implementing new approaches (e.g., Resiliency-Building Approaches to School Discipline, presented in Chapter 6, and Changing Student Attitudes and Behaviours with Policy Revision in Chapter 7), should be constantly evaluated. In Chapter 3 of Part Two, Noonan and Henderson point out that the evaluation of different aspects of the programme "should be a regular ongoing endeavour in every school" (p. 51); they then introduce educators to a step-by-step guide to designing proper research and to improving programmes according to the evaluation the results of various aspects of the programme.

In the eight chapters of Part Three, the most successful programmatic approaches to fostering resiliency within the community are presented. They all express the value of connecting, networking and including various resources to influence community wellbeing and to raise the level of children's and young people's competences, interpersonal relations, mutual help, collaboration and care. The community, particularly educators, needs to support "the value of the application of knowledge over the mere acquisition of knowledge" ( $p$. 86). If we want to raise responsible people we need to give children and young people opportunities to be responsible, opportunities that challenge their talents and capacities, not only their needs, because what gives them confidence and strength is the sense that they can do something for the others, for the community.

The twelve chapters in Part Four focus on creating connections in the sense of mentoring, counselling and support. Sustained relationships and close bonds form one of the fundamental conditions in fostering resiliency. Many research findings highlight that positive relations in the school context have an important influence on the school climate, which strongly correlates with school discipline, learning motivation and consequencely learning effectiveness. "Relationships must be the top priority in any prevention effort or educational reform" (Benard, p. 115), accompanied with effective mentoring programs, supervision and support, especially when volunteers are involved.

Part Five invites us to reconsider resiliency and youth development in a wider sense in order to form a Positive-focused framework for youth, aimed at encouraging their energy, enthusiasm, creativity, morality and caring for the world. Dynamic models are a step forward from "diagnose the problem" models; they enrich the concept towards searching and opening new opportunities for the individual's active approach and for further development, instead of just focusing on 
problem solving. It is again emphasised that such a paradigm shift is important. Dr Benson compares three major American projects: Resiliency, Youth Development, and Asset Development, identifying numerous complementarity factors among them: they all share the same intellectual space, but differ in strategies and target populations. Henderson disputes the statement that resiliency is aimed exclusively at the "at risk" populations, exposing the "high risk and uncertain nature of the world children and youth encounter today, which contributes to the requirement of resiliency for all kids" (p. 169). A great deal of research (e.g., Search Institute research, 1996) highlights a lack of assets in child development in the face of the problems that children encounter daily, in spite of the fact that research shows the significant impact of developmental assets on risky behaviours (p. 175). Henderson also emphasises the growing need to infuse the resiliency attitude, which she summarises as a "strength-based philosophy" (p. 170), across the continuum of all programmes. Instead of labelling people she advocates a resiliency research-based belief: that everyone, irrespective of age, has an innate capacity to bounce back. The next step is to identify and expand individual patterns, so-called resiliency builders that can be used to overcome challenges.

In the nine chapters in Part Six, the authors examine how resiliency can be implemented in families. The family represents the most powerful system in child development, which can be both a protective and a risk factor source. Throughout all of the chapters the importance of strength-focused approaches in family therapy in order to positively meet life's challenges is emphasised, since many research findings show (e.g., Wolin's research on transmitter and non-transmitter families, Wolin \& Bennett, 1984) that even the most troubled families sometimes strongly support children. Both scientists and practitioners of various fields (medicine, education, social sciences) point to the powerful language of damage that has arisen in describing people and their disorders over the years and call for the enrichment of the vocabulary of strengths (p. 195). Such a tendency is also emerging in Slovenian social and educational science, where Dr Gabi Čačinovič Vogrinčič is one of the most enthusiastic advocates of a strength-focused approach and vocabulary that comprise energy, starting points and guidelines for problem solving and managing crises and conflicts (e.g., ČačinovičVogrinčič, 2009). Some research-based parenting programmes are presented in subsequent chapters, given that as adults, whether inside 
or outside the family, our attitudes and choices are powerful determining factors for the future of our children and youth.

There are still new challenges and open questions in resiliency research arising with new findings in neuroscience, genomics, biology, statistics, and the modelling of the development in complex systems, as we can read in scientific reviews (Masten \& Obradović, 2006, p. 23). The eight chapters in the last part of the book look forward to the so-called fourth wave of resiliency research, which focuses on integrating the study of resiliency across levels of analysis, species and disciplines. One of the leading scientists in the field of resiliency, Ann Susan Masten, anticipates Integrative research and collaboration among scientists, which promises to open up new opportunities for basic and applied research. With a transdisciplinary approach we may expect researchers to reveal a much deeper insight into the plasticity of adaptive functioning itself, as well as developing a greater understanding of how processes work within and across levels to nurture resiliency in children.

A neuroscientist Peggy La Cerra, Ph.D., explains how human minds are absolutely unique and multidimensional, and that they constantly change and adapt to the environment. She disputes the term "bouncing back" and remarks that "human brains never return to a previous state but are designed by nature to change with every experience in response to feedback from the environment" (p. 226). Her understanding of resiliency is that it symbolises the "mind that is responding in a way that will enable an individual to thrive in society in large" (p. 226). The other important matter that she exposes is the negative effect of labelling, even positive labelling. Labelling is in direct contradiction to the dynamic and constantly adapting nature of the brain, the mind and the self, therefore cannot be a supportive charge in any case, either for the "at risk" or "gifted" population. She again places emphasis on the value of caring adult support of the child's intrinsic value and potential, which have the power to move the brain, mind and self in the direction of generating successful behaviours. Inspired by Newcomb's article “Adolescence: Pathologizing the Normal Process" (1996), and following Erickson's developmental crisis, in Chapter 3 Trout takes a resiliency-based view of adolescence, and explores the strengths perspective of creating solid identity in this developmental phase, which is characterised by multi-level transition processes. All of the further chapters are based on the resilient brain, which turns out to be a natural trait for all humans. Brendtro 
and Longhurst introduce brain-based strategies that facilitate turning problems into opportunities in Chapter 4. In Chapter 5, the authors invite us to rethink the powerful role of music and music making, something that still attracts a great deal of interest in scientific research of the development of essential cognitive systems (reasoning, creativity, thinking, decision making, problem solving). Henderson emphasises the need and value of play and unscheduled free time, which clearly arises from the neuroscientific aspect, in Chapter 6. She refers to the American Academy of Paediatrics (AAP) Report in 2006, which warned against reducing children's free-time play and physical outlets. Based on recent research findings that point to the predicted and unanticipated contribution of play to education and child development, we can understand play as one of the basic developmental urges, besides sleep, rest, and food; "play, movement, fun, art, creativity, and loving interpersonal interactions filled with sharing pleasurable time together, along with effective and developmentally appropriate discipline are the true predictors of childhood serving as a springboard toward the happy successful adulthood" (p. 243). Finally, in Chapters 7 and 8, the supportive role of Brain Gym movements is highlighted; Brain Gym, developed by Dennison in the early 1980s, is recognised as one of today's leading technologies for education. Brain Gym movements and activities help to strengthen neural connections all over the brain and rebalance brain patterns that have "downshifted in lower, survival brain areas", explains Peterson (p. 246). These findings are especially important for the education of children with special needs, who very often develop into stressed and anxious individuals; they provide an opportunity to facilitate and harmonise the functioning of the individual's mind and body system.

As Benson, Ph.D., remarks in the foreword, the book Resiliency in Action results as a fine combination of theory and practice that makes knowledge and understanding of resiliency paradigm more accessible by challenging reader's head and heart.

\section{References}

Benard, B. (1991). Fostering Resiliency in Kids: Protective Factors in the Family, School, and Community. Retreived May, 12, 2009 from http://hopeworks.org/formation/documents/ FosteringResiliency.pdf. Čačinovič Vogrinčič, G. (2009). Soustvarjanje v šoli : učenje kot pogovor. Ljubljana: ZRSŠ, 2009.

Clay, V. (2005). The Resilience Identification Resources project: a strengths based approach 
to protective and risk factors. 10th National Conference of the Association for the Welfare of Child Health. Retrieved April, 14, 2009 from http://www.awch.org.au/pdfs/ conferences/2005/04_\%20Clay\%2oresilience_paper.pdf.

European Commission (2007). Progress towards the Lisbon objectives in education and training. Retreived February, 14, 2011 from http://ec.europa.eu/education/policies/2010/ progressreport_en.html.

Galimberti, U. (2010). Grozljivi gost: nihilizem in mladi. Ljubljana: Modrijan Masten, A. S., \& Powell, J. L. (2003). A resilience framework for Research, Police and Practice. In S. Luthar (Ed.), Resilience and vulnerability. New York: Columbia University. Luthar, S., Chichetti, D., \& Becker, B. (200o). The Construct of Resilience: A Critical Evaluation and Guidelines for Future Work. Child development, 71(3), 543-562.

Magajna, L. (Ed.) (2008). Učne težave v osnovni šoli: problemi, perspektive, priporočila. Ljubljana: ZRSŠ.

Marzano, R. J. (2003). What works in schools: Translating research into action. Alexandria, VA: Association for Supervision and Curriculum Development.

Masten, S. A., \& Obradović, J. (2006). Competence and resilience in development. In Ann. N.Y. Acad. Sci. 1094 (pp. 13-27). New York Academy of Sciences. doi: 10.1196/ annals. 1376.003

Zakon o organizaciji in financiranju vzgoje in izobraževanja. Uradni list RS, nu. 12/1996. Zakon o organizaciji in financiranju vzgoje in izobraževanja-UPB5. Uradni list RS, nu. $16 / 2007$.

Zakon o organizaciji in financiranju vzgoje in izobraževanja. Uradni list RS, nu. 101/2007. 